\title{
Modeling marine shad distribution using data from French bycatch fishery surveys
}

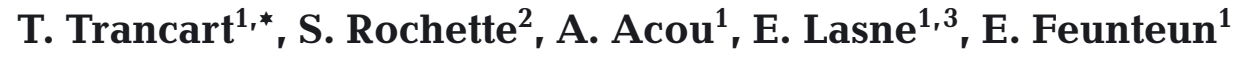 \\ ${ }^{1}$ UMR BOREA 7208, Muséum National d'Histoire Naturelle, Service des Stations Marines, 35800 Dinard, France \\ ${ }^{2}$ IFREMER, Département Dynamiques de l'Environnement Côtier, Applications Géomatiques, CS 10070 Plouzané, France
}

${ }^{3}$ Present address: UMR CARRTEL, INRA/Université de Savoie, 74200 Thonon les Bains, France

\begin{abstract}
In the last few decades, there has been a marked decline in the number of shad (Alosa alosa and A. fallax) landed in France, which prompted the French committee of the International Union for Conservation of Nature to list shad as a 'Vulnerable' species in 2010. The freshwater phases of shad life cycles have been extensively studied, but the marine phases remain poorly understood. The present study aimed to provide new insights into shad ecology by describing the marine distributions of twaite and allis shad using a presence/absence model based on bycatch data from commercial fishery surveys. Depth and salinity were identified as the main factors influencing shad distribution. Both species were primarily located in shallow areas, at depths of between 0 and $100 \mathrm{~m}$. As expected for anadromous species, low-salinity areas were preferred. Substrate and latitude played minor roles in the observed distribution of shad. Our results suggest that latitudinal migration between winter and summer habitats does not occur in twaite and allis shad populations. Furthermore, substrate does not appear to be a key factor contributing to shad distribution. A better understanding of the distribution of shad species throughout their life cycles, particularly in the open sea where they are vulnerable to bycatch, would help in the selection of key protected areas for the sustainability of shad populations.
\end{abstract}

KEY WORDS: Alosa alosa $\cdot$ Alosa fallax $\cdot$ Distribution $\cdot$ Migration $\cdot$ Binomial model

\section{INTRODUCTION}

Shad are a group of anadromous fish species that mature in the sea and spawn in the midstream to upstream sections of rivers, although there are also some landlocked populations. Shad have been extensively studied, particularly in North America. There are 2 sympatric shad species inhabiting the coastal Atlantic waters of western Europe (i.e. the Atlantic Ocean), namely, the allis shad Alosa alosa and the twaite shad Alosa fallax. Since the end of the 20th century, a marked decline in the size and number of shad populations has been observed throughout European coastal waters (Limburg \& Waldman 2009). Several causes have been identified, including dam construction, overfishing, water quality, degradation of spawning grounds (Baglinière \& Elie 2000, De Groot 2002, Limburg \& Waldman 2009), and the Allee effect (i.e. a positive correlation between population density and growth rate) (Rougier et al. 2012). In the Gironde basin, which is known to host the largest populations of both species, stakeholders responded to this reduction by imposing a total moratorium on the shad fishery in 2008. Other conservation measures are also already in place.

One example is the framework of the marine application of the EC Habitat Directive (92/43/ EEC), which compels European Member States to build a network of sites (i.e. the Natura 2000 network) that guarantees the conservation or restora- 
tion of populations of species listed in Annex II (which includes shad) and their associated marine and estuarine habitats. To date, France has listed approximately 207 marine sites under the Habitats and Birds Directives, covering $>41000 \mathrm{~km}^{2}$ of its territory. For shad, Natura 2000 sites were designated using the 'best expert judgment'; exact judgments could not be made because the distribution of shad at sea remains largely unknown. Principal Natura 2000 sites designated for shad (and other diadromous fish species) correspond to estuaries and river plumes of large catchments in the Bay of Biscay, such as the Loire and Gironde Rivers, which are known to host important shad populations. Additional data on the actual distribution of shad at sea would clarify the accuracy of the Natura 2000 network sites.

However, information pertaining to shad in marine areas remains largely lacking. To the best of our knowledge, only Taverny \& Elie (2001) and Sabatié (1993) have studied the spatiotemporal distribution and feeding habitats of European shad at sea. On the basis of an analysis of 20 scientific trawl survey campaigns (1016 stations) conducted between 1986 and 1989, Taverny \& Elie (2001) demonstrated that twaite shads were distributed primarily at water depths $<50 \mathrm{~m}$. Allis shad were observed in waters deeper than $100 \mathrm{~m}$. The distributions of allis and twaite shad showed that they aggregated and were located in the river mouths of the most important watersheds (the Gironde and Loire). However, shad distributions at sea could have changed since the late 1980s as a result of marine trophic and thermal changes; thus, it is important to update and expand upon this information using a more recent dataset. Shad are not targeted at sea but are caught as bycatch. Bycatch is a critical source of mortality for marine species and socalled 'trash fish' species (the importance of which in marine food webs is now being recognized). Finally, data on shad ecology and distributions at sea are required in order to implement efficient conservation policies.

To increase knowledge on the distribution of shad at sea, we used a large and recent (2003 to 2010) dataset comprising observations taken onboard fishery fleets (i.e. the ObsMer program). The present study aimed to use these data to develop a habitat suitability model and predict distribution maps for allis and twaite shad. Combined with an analysis of seasonal variations, knowledge of their spatial marine distribution and ecology could permit more effective management, such as a relevant delimitation of the Natura 2000 network at sea.

\section{MATERIALS AND METHODS}

\section{Fisheries data: the ObsMer program}

In France, the ObsMer program manages all the marine observations required by fisheries regulations. It aims to gather information to minimize bycatch and assess the incidental catches of endangered species, mainly cetaceans and turtles but also migratory fish, such as shad. Onboard, scientific observers randomly sampled bycatch from 9049 commercial catches between 2003 and 2010. In the ObsMer database used in the present study, the mesh sizes of trawls ranged from $6 \mathrm{~mm}$ (glass eels boats) to $320 \mathrm{~mm}$ (tuna boats). A total of 43 types of gear were used to catch 68 different marine species, from the coast to the continental slopes. Preliminary analysis showed that, with the great number of different fishing gears and different target species, the number of fishing operations likely to capture shad remained steady in time and space.

Allis and twaite shad (Alosa alosa and A. fallax, respectiviely) were systematically reported, when present, thus assuring no false absence in the sample/ trawl. Observations included the dates, locations of the trips (i.e. latitude and longitude), fishing gear, and the number of twaite and allis shad (when present). The data used in this study were collected from the middle of the Bay of Biscay to the English Channel, ranging from 51.08 to $45.22^{\circ} \mathrm{N}$ and -6.09 to $1.45^{\circ} \mathrm{E}$ (Fig. 1). Fish total length, for the few samples reported, ranged from 50 to $690 \mathrm{~mm}$ for allis shad and from 100 to $640 \mathrm{~mm}$ for twaite shad. This length range indicated that juveniles (i.e. $<100 \mathrm{~mm}$ ) and mature adults (i.e. $>430 \mathrm{~mm}$ ) were included in the database. However, as biometry was rarely reported, possible juveniles were not separated from adults in the analyses. About $84 \%$ of the shad observed in this database were collected with only 5 different types of fishing gear, the types most commonly used by professional fishermen (representing $60 \%$ of total effort). Previous analysis showed that there is no spatial bias in gear type and no seasonal bias in the location of trawls and nets associated with shad bycatch. We thus assumed that the present bycatch data were representative of shad distribution at sea.

The limited number of observations with biometry did not allow us to account for differences in measurements among the various types of fishing gear utilized. Therefore, only presence/absence data were used. These data, sometimes considered 'basic', can lead to inferences regarding the ecology and distribution of a species (MacKenzie 2005, Vojta 2005). 


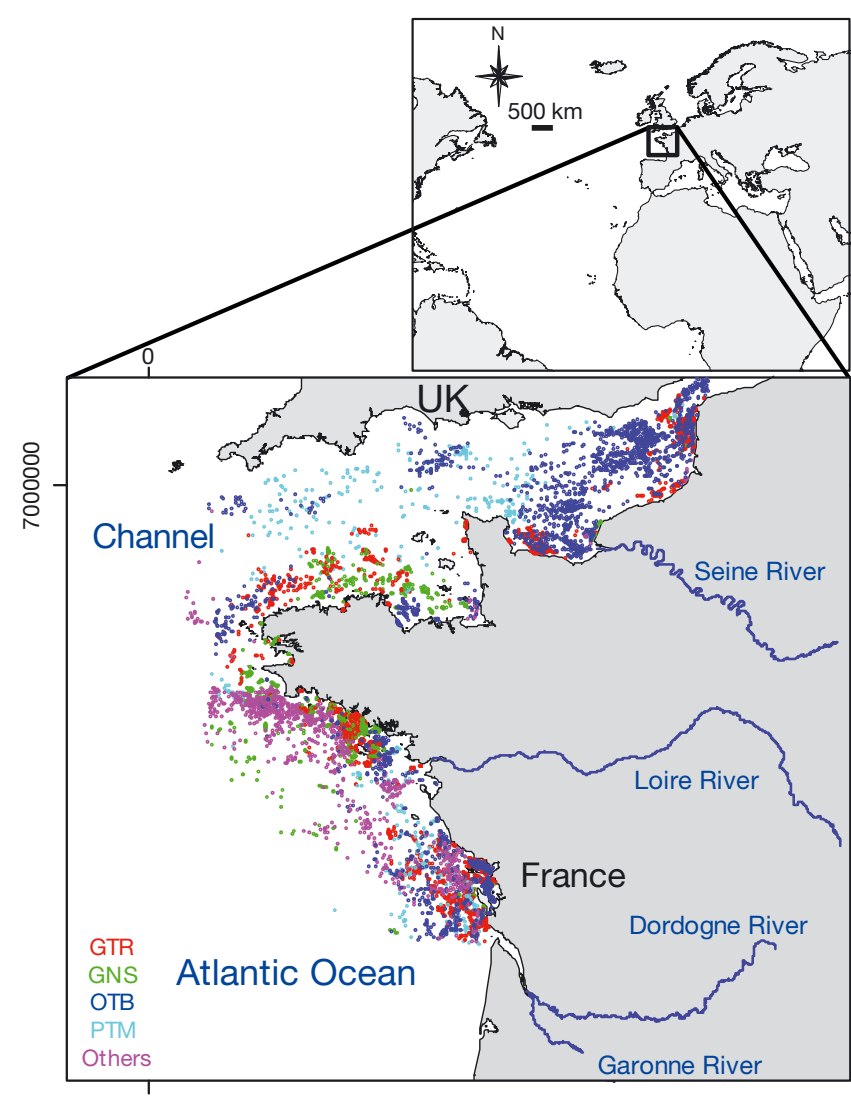

Fig. 1. Global position of the study site. Locations of all commercial surveys from the dataset. Trammel-nets (GTR) caught $19.97 \%$ of shad (Alosa spp.); fixed gill nets (GNS), $18.69 \%$; benthic bottom otter trawls (OTB), $16.31 \%$; midwater trawl (PTM), $15.55 \%$; and others, $29.48 \%$

\section{Grid system principle}

Shad were not frequently present in the catches of the database. Thus, data were unbalanced in favor of the absence of shad, which did not allow either a correct fit for the habitat suitability model or robust distribution mapping. Indeed, Liu et al. (2005) recommended a good balance between the presence and absence data so that the threshold value separating the modeled probabilities of presence into presence or absence would be $\sim 0.5$.

As the occurrence of shad was rare in the collected samples, we assumed that a single observation of a shad at a specific site was an indication that the site contained suitable shad habitat, even if absence was recorded more frequently. Following this assumption, we divided the study area into a regular grid of $20 \times 20 \mathrm{~km}$. For each grid cell, the central point was assigned a value of 1 if at least 1 individual was observed within the grid cell, and a value of 0 was assigned for the total absence of shad; no value was assigned if no observation was made. This grid cell dataset was used for the modeling. A sensitivity analysis completed the approach by testing for the effect of $10 \times 10 \mathrm{~km}$ and $40 \times 40 \mathrm{~km}$ grid cells. This methodology was presented by Keil et al. (2013).

\section{Environmental descriptors}

Habitat suitability modeling allows the presence/ 8 absence data to be linked to environmental descriptors. Environmental variables that might influence shad distribution at sea were selected for testing in the models and included the following: (1) depth, which has been cited as a strong structuring factor (Taverny \& Elie (2001)); (2) salinity and temperature, which are known to have direct physiological effects on anadromous fish (Zydlewski et al. 2003, Boisneau et al. 2008); (3) latitude, which is considered a proxy for large-scale temperature regimes and ecosystem functioning; and (4) the substrate, which can be considered a proxy for food availability. The average value of the environmental variables was allocated to the grid cell centers. Variables were obtained from the following sources.

- Bathymetry was produced by the SHOM (Service hydrographique et océanographique de la marine) and IFREMER (Institut Français de Recherche pour l'Exploitation de la Mer) at a $200 \mathrm{~m}$ resolution (Loubrieu et al. 2001). This was transformed to a class factor for statistical analyses as follows: 0-50, 50-100, and 100-150 m. No shad were found deeper than $150 \mathrm{~m}$.

- A sediment map was provided by IFREMER (modified from Chassé \& Glémarec 1976, Larsonneur et al. 1979, Lesueur \& Klingebiel 1986). Three classes of sediment were used according to grain size: mud ( $\leq 2 \mathrm{~mm})$, sand (>2 and $\leq 4 \mathrm{~mm})$, and gravel or coarse grains $(>4 \mathrm{~mm})$; the sediment size allocated to a grid cell was the size that was primarily represented in the cell.

- All the geographical data used in the present study are based on coordinates of the Lambert-93 projection, the official system in France, which gives the coordinates directly in meters.

- Salinity (\%) and temperature $\left({ }^{\circ} \mathrm{C}\right)$ at the surface were provided by the MARS3D hydrodynamical model at a $4 \mathrm{~km}$ resolution (Lazure \& Dumas 2008), coupled to ECOMARS3D for the physical parameters (PREVIMER project). Both variables were extracted as monthly means. Three salinity classes (31-33, 33-35, and >35 PSU) and 6 temperature classes $\left(8-10,10-12,12-14,14-16,16-18\right.$, and $\left.18-20^{\circ} \mathrm{C}\right)$ were utilized. 


\section{Temporal descriptors}

Spatial distributions of organisms such as fish may vary depending on the time of year, as a result of temporal changes in trophic or reproductive behaviors.

Three temporal scales were examined in the models, including seasonal (4 modalities: spring, summer, autumn, and winter), bimonthly (i.e. every 2 mo with 6 modalities starting in January/February and ending with November/December), and monthly (12 modalities) scales.

\section{Selectivity of fishing gear}

The grid system approach did not account for the fishing gear. However, it is well known that different types of fishing gear have different degrees of selectivity. The ObsMer data revealed the presence of shad primarily in trawl and net fishing. In order to evaluate this potential bias, we performed a preliminary test that did not reveal a geographic trend in the use of fishing gear, indicating that the use of each type of fishing gear occurred in similar proportions throughout each square of the grid system. No temporal effect on any type of fishing gear was observed in preliminary tests.

\section{Modeling process}

A generalized linear model (GLM) was applied to the presence/absence survey data (binomial model with a logit link function) in order to describe the distribution of the 2 shad species with respect to the temporal parameters (i.e. month of capture, bimonthly period, or season) and environmental factors as follows:

Logit(p0/1) $\approx$ Temporal parameters + Environmental factors $\times$ Temporal scale

All possible combinations using 1 to 5 physical parameters, including interactions when relevant, were tested. The model that best fit the observed data and allowed predictions was chosen according to 2 indicators: (1) the accuracy of the prediction was estimated using a bootstrap cross-validation, and null and residual deviances for each validation were averaged to obtain a mean deviance explained by the cross-validation; and (2) the parsimony of the model was evaluated based on the Akaike Information Criterion (AIC) (Akaike 1974).

For cross-validation, a random subset of $80 \%$ of the dataset was used for parameter estimation. The prob- ability of presence and the explained deviance for each of the remaining $20 \%$ of observations (validation dataset) were calculated. This procedure was replicated 1000 times, and the mean explained deviance was calculated for each model tested. Models with all possible combinations of variables were tested using the same 1000 estimation-validation random subsets. Models yielding the smallest AIC, with the best mean explained deviance, were retained for the analysis and utilized for predicting the habitat suitability distribution of shad. To evaluate the efficiency of the selected model, the Area Under the Curve (AUC) method (Hanley \& McNeil 1982) was performed, giving the percentage of good predictions in the previous cross-validation loops.

Figures representing the effects of the physical parameters in the following results section are shown with the uncertainty of prediction for the average effects of variables. The average effect of a variable was obtained from the following method: for each combination of the other factors, a prediction of the probability of presence was obtained from Eq. (1). The predictions for each combination of factors were then averaged to obtain the mean variable effect. Uncertainty was estimated by Monte Carlo sampling (5000 trials) in the estimation distribution of each parameter needed to compute the prediction in Eq. (1).

All descriptive statistics, models, and prediction maps were made with the R CRAN free software environment (http://cran.r-project.org/). Probability values were considered statistically significant for $\mathrm{p}<$ 0.05 .

\section{RESULTS}

\section{Grid and seasonal approach selection}

The change in the spatial grid resolution $(10 \times 10$, $20 \times 20$, or $40 \times 40 \mathrm{~km}$ ) revealed no influence on the selected combination of physical parameters and yielded only marginal visible changes in the predicted distributions. Hence, only the $20 \times 20 \mathrm{~km}$ grid resolution is discussed hereafter. For the temporal scale, only the $6 \times 2$ mo scale is presented in the 'Results' section. The monthly scale was too small to allow a robust estimation of the parameters; the amount of presence data was too limited and the number of degrees of freedom was too high when using interactions between temporal and physical parameters. Conversely, the seasonal scale was too coarse to capture the temporal variability in shad distributions. 


\section{Models selected and evaluation}

According to the 2 selection methods (smallest AIC with the best mean explained deviance via cross-validation), the distributions of both shad species were best explained by the following variables:

$$
\begin{aligned}
& \operatorname{logit}\left(\operatorname{Shad}_{0 / 1}\right) \approx \text { Salinity:Time }(2 \text {-mo-period }) \\
& \quad+\text { Depth:Time }(2 \text {-mo-period }) \\
& \quad+\text { Sediment:Time (2-mo-period }) \\
& \quad+\text { Latitude:Time (2-mo-period) }
\end{aligned}
$$

where $\mathrm{Shad}_{0 / 1}$ is the probability of shad presence. These AUC indexes were 0.8151 for allis shad (Alosa alosa) and 0.7697 for twaite shad (A. fallax).

\section{Analysis of allis shad model factors}

The effect of depth dominated the explained deviance of the allis shad data (Table 1). Although significant, the effect of sediment was low. Allis shad showed a clear global preference for lowsalinity areas (31 to 33 PSU), shallow areas $(<100 \mathrm{~m})$, low-latitude areas, and muddy substrates (Fig. 2).

Taking into account the temporal variation, we present the following general overview for allis shad (Fig. 3):

Depth: The combination of depth with the 2 mo temporal scale showed slight variations in depth preference in the fifth temporal class (September-October) and presence in deeper areas during MarchApril (Fig. 3).

Salinity: Shad appeared to be present in areas of low salinity ( 31 to 33 PSU) during most of the year, but this preference was inverted in the fifth class (September-October) (Fig. 3).

Latitude: The preference for lowlatitude areas (Fig. 2) was clear for 10 of 12 mo of the year, including MarchDecember. The difference was less notable from January to February, when the probability of presence was low (Fig. 3).

Substrate: The differences in substrate effects changed throughout the year (Fig. 2). Although gravel appears to be an unsuitable substrate for shads, the differences between sand and mud may have arisen from a sampling effect.
Analysis of twaite shad model factors

Depth was the main factor influencing the presence of twaite shad (Table 2). The effect of sediment had a probability of $\mathrm{p}=0.055$, but the cross-validation approach showed a gain in explained deviance, thus reflecting its importance in predictions. The analysis indicated a strong global preference for areas of low salinity, depth, and latitude, and areas that contain gravel (Fig. 4).

Depth: According to the model, shallow depths were clearly preferred throughout the year, except from January to February, when the probability of twaite shad presence was low (Fig. 5).

Table 1. Analysis of deviances for the Alosa alosa binomial generalized linear model

\begin{tabular}{|lrrr|}
\hline & df & \multicolumn{2}{c|}{$\begin{array}{c}\text { Explained } \\
\text { deviance (\%) }\end{array}$} \\
& \multicolumn{3}{l}{ p-value } \\
\hline Salinity:Time (2-mo-period) & 6 & 6.19 & $4.40 \times 10^{-13}$ \\
Latitude:Time (2-mo-period) & 6 & 5.98 & $1.33 \times 10^{-12}$ \\
Depth:Time (2-mo-period) & 18 & 7.82 & $2.91 \times 10^{-11}$ \\
Sediment:Time (2-mo-period) & 9 & 2.32 & $1.87 \times 10^{-3}$ \\
Total (\%) & & 22.31 & \\
\hline
\end{tabular}
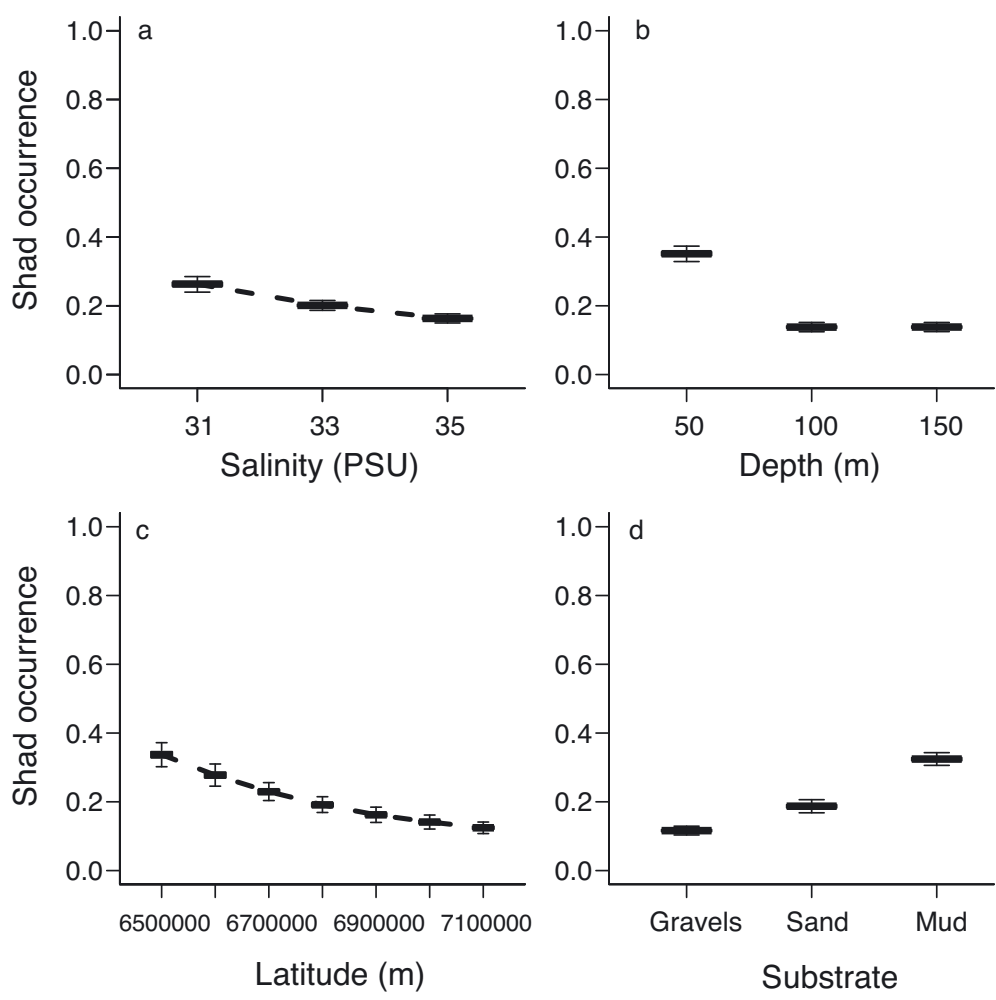

Fig. 2. Alosa alosa. Global effects of the 4 main parameters on allis shad occurrence: (a) salinity (PSU), (b) depth (m), (c) latitude (m) and (d) substrate 

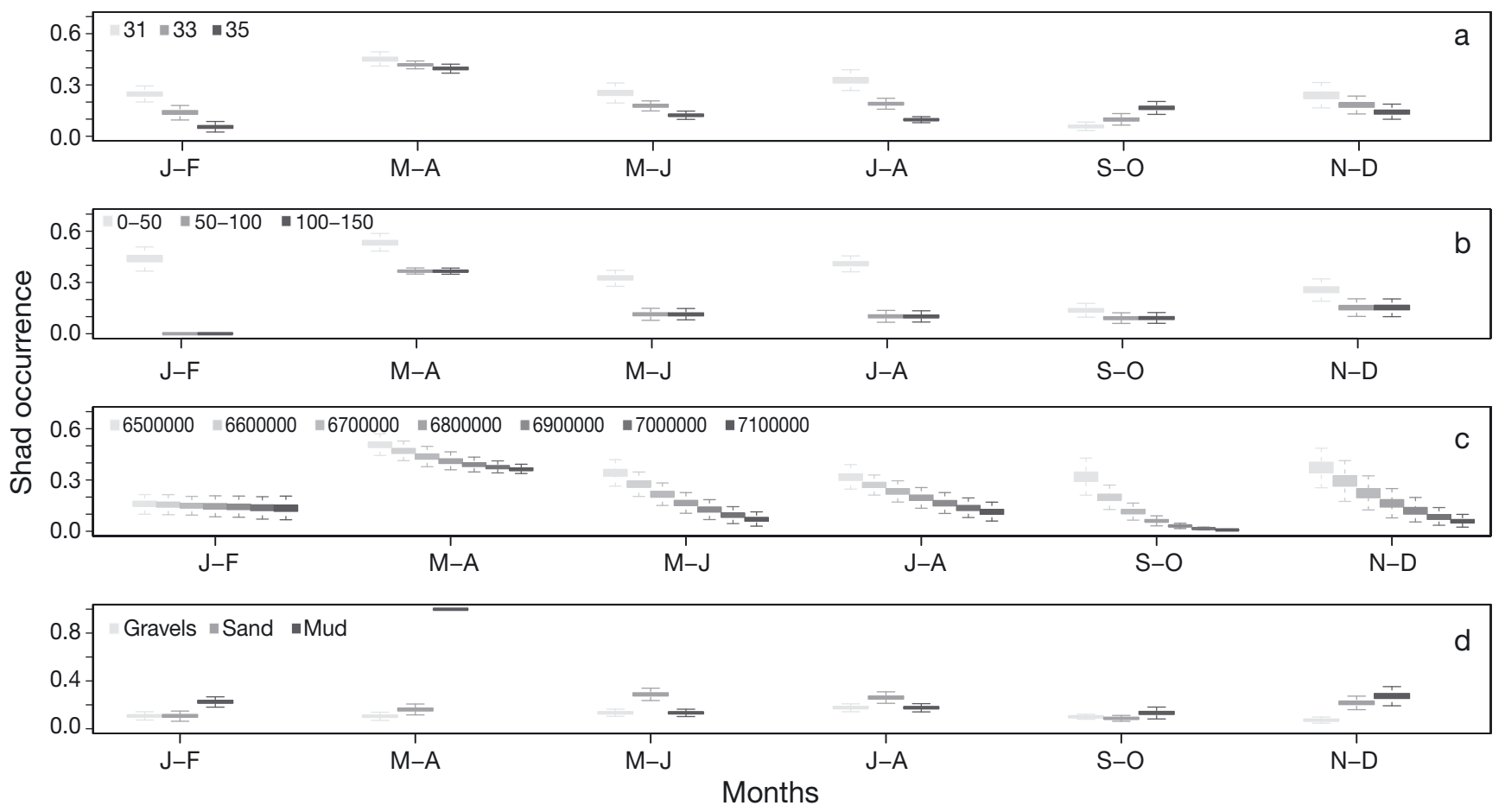

Fig. 3. Alosa alosa. Two-month-period approach for allis shad: temporal change for the 4 main parameters: (a) salinity (PSU), (b) depth $(\mathrm{m})$, (c) latitude $(\mathrm{m})$ and $(\mathrm{d})$ substrate. $X$-axis: from January-February (J-F) to November-December (N-D)

Salinity: The preference for lower salinity was primarily correlated with the period from January to April; the distribution of twaite shad was homogeneous throughout the remaining months of the year (Fig. 5).

Latitude: The effect of latitude was small but was retained in the selection method because it appeared to be changing throughout the year, thus showing a higher probability of presence in the north from January to April and in the south throughout the remainder of the year (Fig. 5).

Substrate: The positive effect of a hard substrate was more pronounced from January to March but was almost insignificant throughout the remainder of the year (Fig. 5).

Table 2. Analysis of deviances for the Alosa fallax binomial generalized linear model

\begin{tabular}{|lrrr|}
\hline & df $\begin{array}{c}\text { Explained } \\
\text { deviance } \\
(\%)\end{array}$ & p-value \\
& \multicolumn{3}{c|}{} \\
\hline Salinity:Time (2-mo-period) & 6 & 3.95 & $2.18 \times 10^{-6}$ \\
Latitude:Time (2-mo-period) & 6 & 5.77 & $9.96 \times 10^{-10}$ \\
Depth:Time (2-mo-period) & 18 & 9.74 & $1.38 \times 10^{-11}$ \\
Sediment:Time (2-mo-period) & 10 & 0.95 & $5.49 \times 10^{-1}$ \\
Total (\%) & & 20.41 & \\
\hline
\end{tabular}

Distribution prediction for Allis and twaite shad

Prediction maps were generated using the models selected and merged with the maps of physical variables. For allis shad, the maps predicted distributional patterns for the following 3 time periods (Fig. 6): (1) During the first 2 mo (January and February), allis shad would be minimally present in the sea and primarily localized near estuaries or in coastal areas, mainly in Natura 2000 areas; (2) from March to August their presence was predicted in coastal areas; and (3) from September to December, the models predicted the presence of shad in oceanic waters.

Although the 3 temporal distributions observed in the twaite shad prediction maps were similar to those for allis shad, some differences were noted (Fig. 7): (1) From January to February, twaite shad were predicted to occur primarily in the English Channeli (2) from March to August, a high concentration of twaite shad was predicted in coastal waters, including areas protected by the Natura 2000 network; they were also predicted to occur in coastal waters more often than the allis shad; and (3) from September to December, they were predicted to move to oceanic waters. 

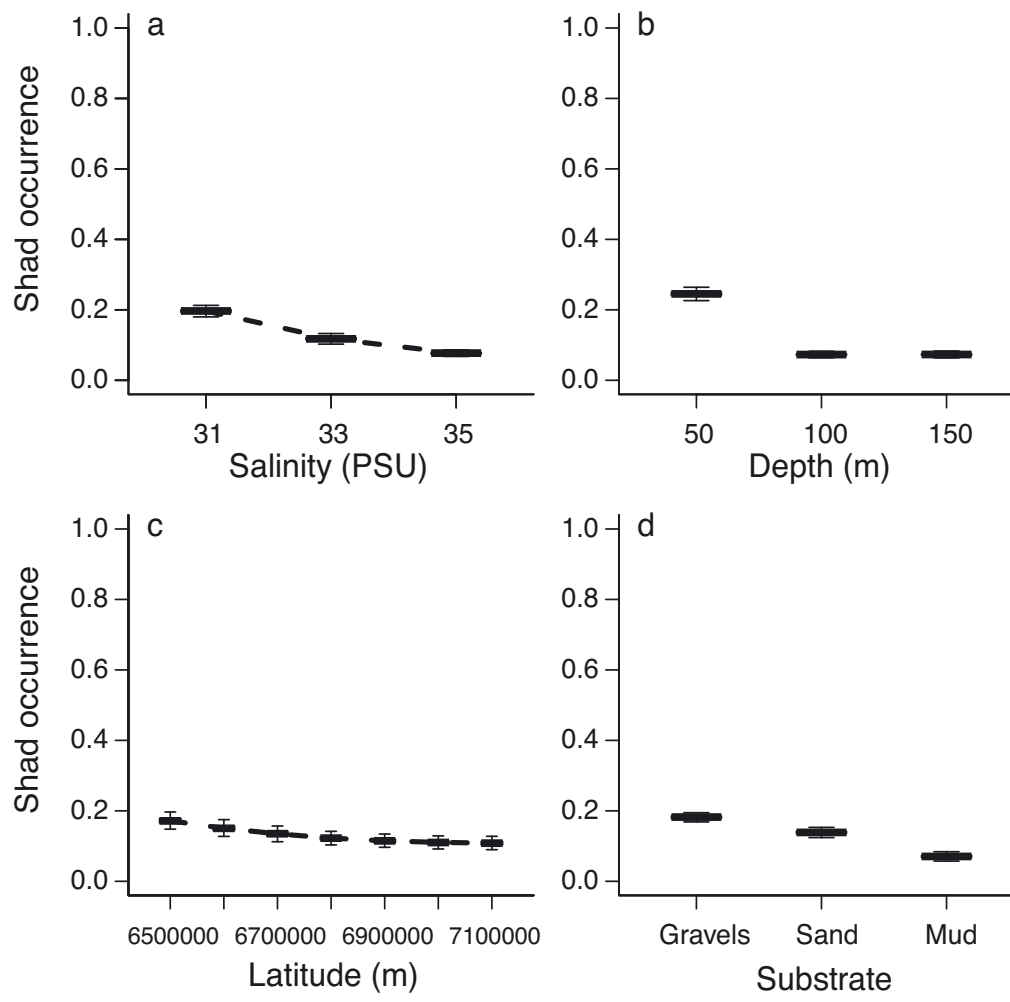

Fig. 4. Alosa fallax. Global effects of the 4 main parameters on twaite shad occurrence: (a) salinity (PSU), (b) depth (m), (c) latitude (m) and (d) substrate

\section{DISCUSSION}

There is a considerable lack of knowledge with regard to the distribution of European shad species (Alosa alosa, A. fallax) in the sea, which limits the development of efficient population management policies. The absence of shad fisheries at sea may explain the lack of interest; commercial fisheries prevail only in estuaries. Additionally, very few scientific studies have focused on the ecology of shad during the marine stages of their life cycles. The present study aimed to compensate for this gap in knowledge by using marine fisheries bycatch data, which provided new information on shad species ecology and distribution.

\section{Limitations of the methodology}

Our model and the sensitivity analysis were built using bycatch data. To date, studies using bycatch data are not widespread (see for instance Dell et al. 2011).
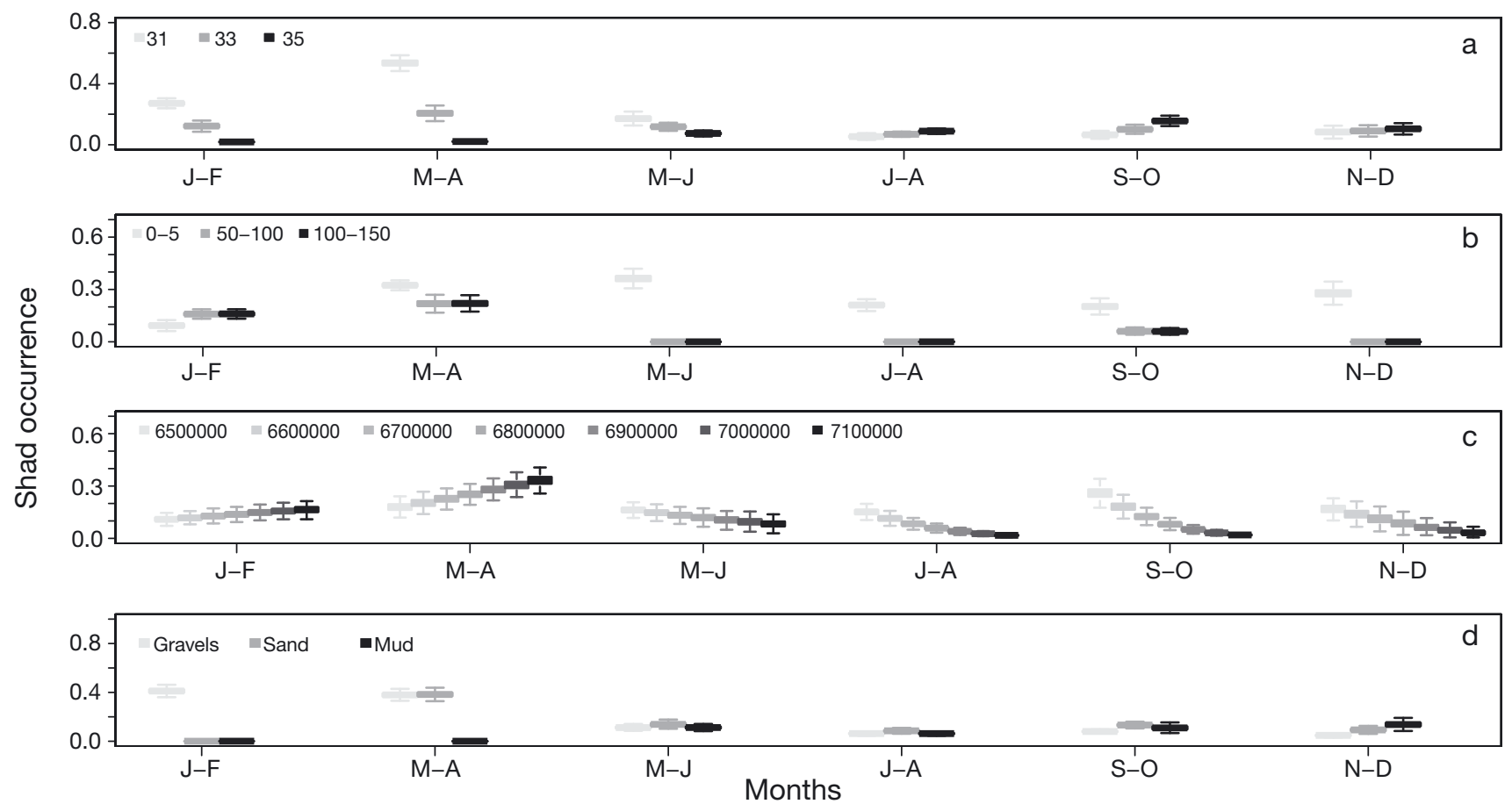

Fig. 5. Alosa fallax. Two-month-period approach for twaite shad: temporal change for the 4 main parameters: (a) salinity (PSU), (b) depth $(\mathrm{m})$, (c) latitude $(\mathrm{m})$ and (d) substrate. $X$-axis: from January-February (J-F) to November-December (N-D) 

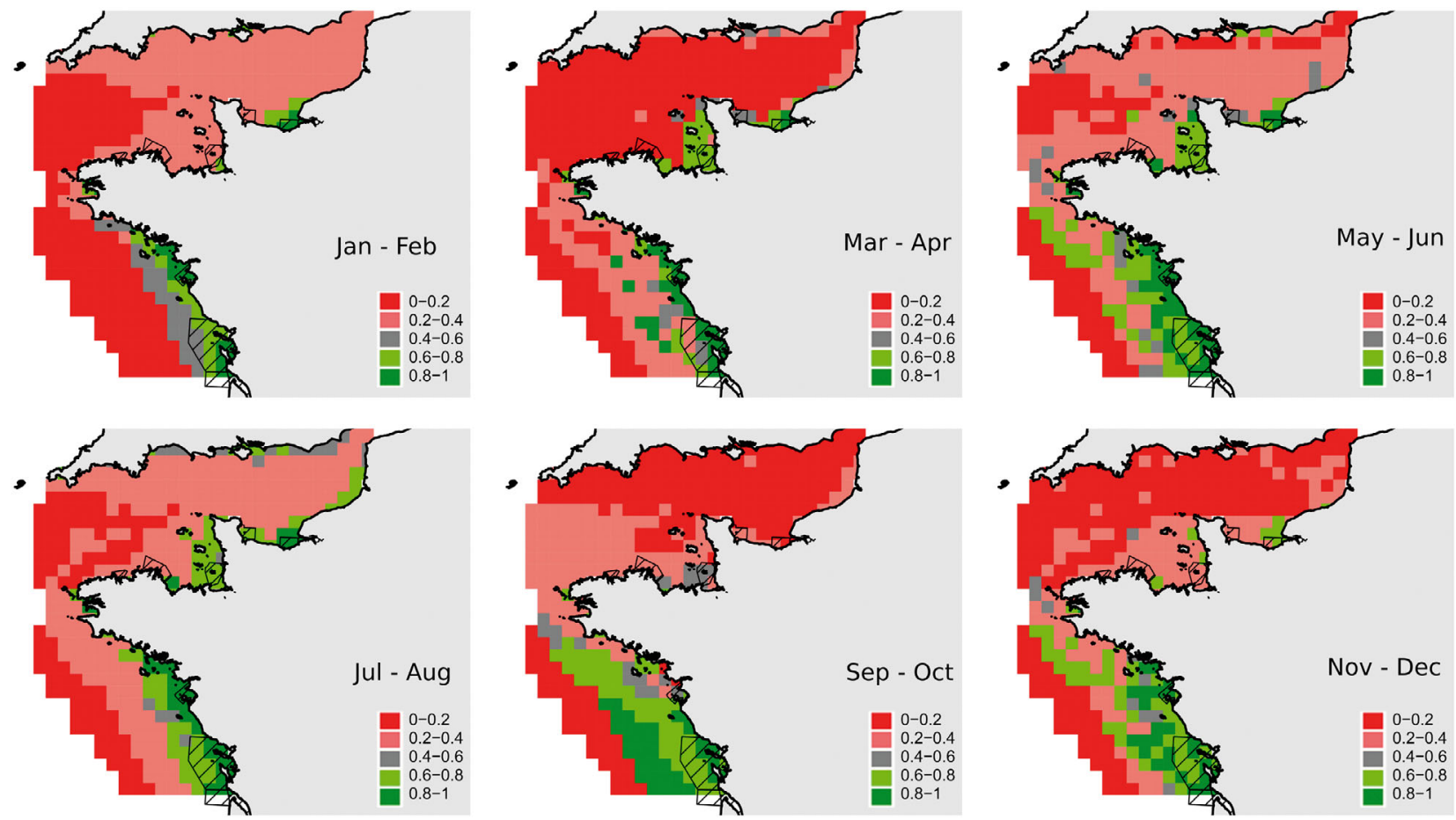

Fig. 6. Alosa alosa. Prediction maps for allis shad $(20 \times 20 \mathrm{~km}$ cells $)$ in the 2-mo-period approach. Colors show probabilities. Probabilities $<0.4$ may indicate the absence of shad. Striped areas indicate Natura 2000 shad-designated sites
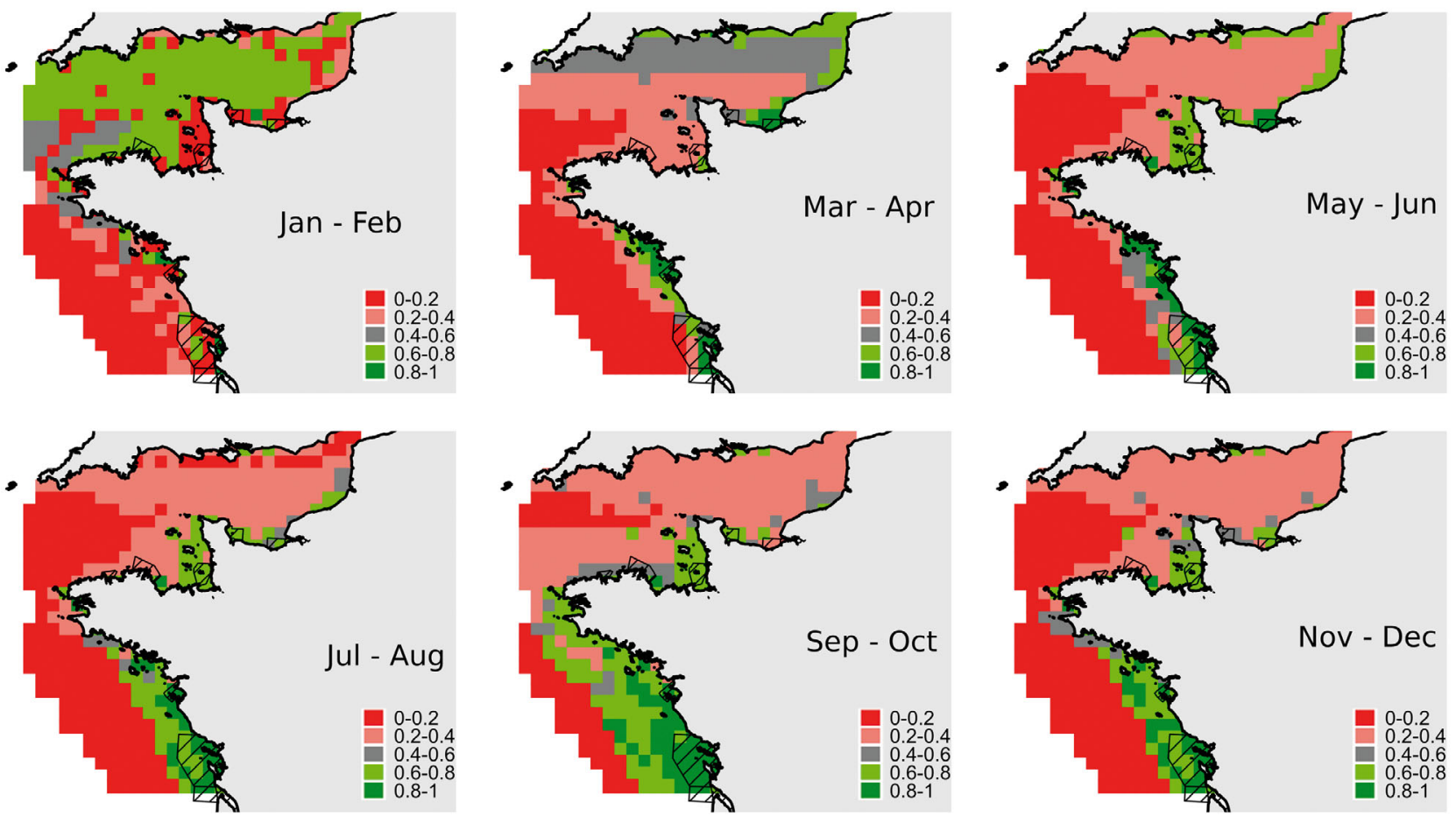

Fig. 7. Alosa fallax. Prediction maps for twaite shad $(20 \times 20 \mathrm{~km}$ cells $)$ in the 2-mo-period approach. Colors show probabilities. Probabilities $<0.4$ may indicate the absence of shad. Striped areas indicate Natura 2000 shad-designated sites 
We assumed that bycatch data could be used to model habitat preferences for 3 main reasons:

1. Shad are not a target species because their population is limited and not commercially interesting for professional exploitation.

2. Even if shads are not targetted, their pelagic behaviour makes them very vulnerable to fisheries focused on the main commercial species, like mackerel, herring or anchovy."

3. Commercial fisheries data are often considered biased with respect to mapping species distributions because fishers choose to target species at the center of their distribution to maximize catches and minimize search costs (Dell et al. 2011). In the present study, we have used a considerable database (>9000 trawls), representing numerous types of fishing gear (43) and a large range of mesh sizes (6 to $320 \mathrm{~mm}$ ), that was not focused on shad and therefore is not biased. The use of such a database could reduce the potential bias linked to bycatch. Preliminary analysis was also done to support this conclusion.

Thus, we think it is reasonable to assume that bycatch data are adequate to model species presence.

Commercial fisheries focus on large fish (with the exception of specific fisheries such as those for glasseels or shrimp). In this context, it is relevant to address the question of the representativeness of the size distribution in the catches. Records of fish length were not sufficiently accurate to be integrated into the models. A simple descriptive analysis showed that the smallest total length of an individual fish in the database was $50 \mathrm{~mm}$, suggesting that young-ofthe-year (i.e. $<100 \mathrm{~mm}$; Lochet 2006) samples could be integrated into the ObsMer database. Future studies should integrate information on fish size into the analyses, because habitat-use patterns might be size/age dependent; however, it is reasonable to assume that the models were sufficiently representative of the entire shad population in the field. Another limit may be the absence of data for areas closer to English coasts; this may create bias with regard to the effect of high latitude. Thus, the northernmost effects, particularly for twaite shad, should be interpreted with caution.

\section{Model efficiency}

The first indications of the efficiency of the model developed in the present study were the good AUC indexes observed in the cross-validation procedure, showing that $>76 \%$ of predictions from both models (allis and twaite shad) were good.
Moreover, the depth effect observed in the current model is in accordance with the literature. Allis and twaite shad were not observed at depths $>150 \mathrm{~m}$, which was used as a limit for the model. The factor analysis from our models showed that allis and twaite shad primarily selected depths of 0 to $50 \mathrm{~m}$. In the wild, allis shad around Morocco are found at depths of 30 to $150 \mathrm{~m}$, near areas of summer upwelling (Sabatié 1993). Allis and twaite shad were also found to inhabit shallow waters, 15 to $115 \mathrm{~m}$, along the northwest coast of France (Taverny \& Elie 2001). In our model, fish were caught from depths of 15 to $115 \mathrm{~m}$. In total, 100 and $78 \%$ of twaite and allis shad, respectively, were caught at depths $<100 \mathrm{~m}$. Twaite shad tended to occur at shallower depths than allis shad (Baglinière \& Elie 2000), as represented in our model (Figs. 2 \& 4).

Moreover, the oceanic distribution of another shad species, the American shad A. sapidissima, along the Pacific coast of North America is primarily confined to the continental shelf (Pearcy \& Fisher 2011). No evidence for large-scale seasonal migrations has been found in this area (Pearcy \& Fisher 2011), although such migration has been reported on the Atlantic coast (Neves \& Depres 1979), corroborating results from our model. In this study, shad were caught in shallow waters (depths $<150 \mathrm{~m}$ ). Along the Atlantic coast, the majority of shad have been captured at depths <100 m (Neves \& Depres 1979). Nevertheless, some shad were caught at greater depths, 150 to $>200 \mathrm{~m}$ (Neves \& Depres 1979), and an increased frequency of shad presence was found at depths $>60$ m (Bethoney et al. 2013). This association with deeper areas corresponded to shad winter habitats (Neves \& Depres 1979, Bethoney et al. 2013).

The salinity was also initially described as a migration factor for American shad (Dodson et al. 1972). The authors showed that the high decrease in salinity was a physiological dam for the inland migration of shad, requiring meandering between salt and freshwater.

All these studies confirm the results of our model. However, again for American shad, Leggett \& Whitney (1972) showed that water temperature was the main cue for inland migrations. The authors observed that $90 \%$ of the runs take place when river temperatures are between 16 and $19.5^{\circ} \mathrm{C}$. However, in our model, water temperature was tested but not selected by AIC and cross-validation selections. We can assume that water temperature was correlated with the interaction between depth and month, leading to its rejection by the selection procedure. 


\section{Latitudinal effect: Do fish remain in the same geographic area throughout the year?}

Latitudinal factors appear to have marginal effects on the distribution of twaite and allis shad: the probability of capturing shad is nearly constant along the latitudinal gradient. On the basis of a global analysis, the distribution of allis shad was slightly further south than that of twaite shad. This result is in accordance with Baglinière \& Elie (2000) who highlighted that the most important allis shad population was found at the mouth of the Loire River (France, $47.2654^{\circ} \mathrm{N}$ ), the southernmost region of the present study area. Our analysis showed a twaite shad preference for more northern latitudes, which is in accordance with the literature. From an extensive bibliography review, Lassalle et al. (2008) identified the presence of allis shad from the Sebou Estuary (Morocco) to the Solway Firth (United Kingdom), with small populations in Sebou. Baglinière \& Elie (2000) observed an important twaite shad population in the coastal waters of the United Kingdom and the North Sea.

According to our bimonthly analysis, no change in the effect of latitude was observed for allis shad, which may suggest the absence of massive latitudinal migration between winter and summer habitats. This indicates that, in general, allis shad populations remain in the same geographic area throughout the year, undertaking only longitudinal (i.e. river to ocean) migrations. Nevertheless, individual surveys are required to confirm this migration pattern because the picture provided by the bycatch data may conceal individual variation in space-use behavior. Conversely, a slight difference was observed for twaite shad, which may be due to variations in the timing of their upstream migration from south to north.

\section{Substrate preference: an opportunist trophic cline?}

The sensitivity analysis from our model showed that there was a greater presence of allis shad in areas with muddy substrates than in areas with other types of habitats. From the output of the model, twaite shad showed a weak preference for gravel. It is generally accepted that fish diet and home-range substrate are closely linked. Allis shad feed on a wide range of planktonic crustaceans; larger adults feed on small schooling fish (Whitehead 1985, Rochard \& Elie 1994). Twaite shad are more ichthyophagous, feeding on small fish and crustaceans (Whitehead 1985, Rochard \& Elie 1994). This difference in shad diets could explain the difference in substrate prefer- ences. The preference for soft bottoms and hard substrates for allis shad and twaite shad, respectively, was more pronounced during periods yielding higher probabilities for the presence of shad overall or for each species.

\section{Allis shad pattern of oceanic movements}

Our results from the model for allis shad movement patterns at sea over the course of a year are in accordance with the classical view of the life cycles of anadromous species derived from freshwater and estuarine observations; they also could provide additional information on movement patterns within marine habitats (e.g. distribution and timing).

It should be noted that the model used in the current study was capable of analyzing the temporal variations in the distribution of shad. In winter (January and February), allis shad were preferentially present in the $0-50 \mathrm{~m}$ depth class and low-salinity areas of coastal and estuarine regions. However, the model predicted low occurrence probabilities, which indicated that a large portion of the shad populations had not been sampled at sea. It appears that the shad inhabited the inner estuaries or rivers during this period. From March to August, the model showed that allis shad were primarily shown to live in coastal areas, with a preference for shallow depth and lowsalinity environments. Taking into consideration the migration phenology and information available from reproductive studies in riverine environments, this shift in distribution may be related to the spawning migration. During the last part of the year, allis shad were observed to move from coastal to oceanic areas. This movement was also confirmed by factor analysis, which indicated minimal differences in depth and salinity preferences. Because allis shad are primarily semelparous (Baglinière \& Elie 2000), we cannot conclude that this movement corresponds to the downstream migration of post-reproductive adults. Nevertheless, the young-of-the-year may have reached a length of $100 \mathrm{~mm}$ by this time of the year (Lochet 2006), suggesting that they could be integrated into the ObsMer database and, therefore, our model. Hence, this migration could comprise some iteroparous adults and young-of-the-year individuals.

\section{Twaite shad pattern of migration}

From the outputs of the model, twaite shad exhibited similar patterns of movement to allis shad; the 
prediction maps and factor analysis also suggested an annual 3-step marine distribution. Some slight differences were noted, however. From January to February, twaite shad were mainly located in English waters, with an almost uniform distribution (with no preference for shallow depth areas). In the second step, with regard to allis shad, movement toward coastal areas was observed between March and August, with a strong preference for areas of shallow depth and low salinity. We can assume that this represents iteroparous adults and young-of-the-year fish. This assumption is in accordance with Baglinière \& Elie (2000). In the last part of the year, the results suggest a strong movement toward oceanic areas. Because twaite shad are iteroparous (Baglinière \& Elie 2000), this movement could represent a second annual migration, from coastal to oceanic areas. The distribution of recorded fish lengths also suggests that young-of-the-year individuals were present in the migrating population (Baglinière \& Elie 2000).

On the basis of the model global analysis, allis shad distribution was slightly more southerly than that of the twaite shad. This is in agreement with Baglinière \& Elie (2000), who showed that the most important allis shad population was found at the mouth of the Loire River (France, $47.2654^{\circ} \mathrm{N}$ ). Lassalle et al. (2008) found allis shad to be present from the Sebou Estuary (Morocco) to the Solway Firth (United Kingdom), with small populations in Sebou. Indeed, Baglinière \& Elie (2000) noted an important twaite shad population in the United Kingdom and North Sea.

\section{Pertinence of the Natura 2000 network at sea}

The results of the current study indicate that the Natura 2000 areas are not entirely pertinent for shad protection management. Allis and twaite shad inhabit a high proportion of the Natura 2000 areas only from January to April and March to June, respectively. Indeed, although shad live in relatively shallow waters, their life cycle is not limited to coastal regions, and thus managing this species via Natura 2000 management is necessary but not sufficient. Moreover, although the 2 most important French basins (Loire and Gironde) are included in the Natura 2000 network, there are additional basins that could be considered equally as important for shad distribution according to our models. For instance, to date, the Vilaine and Scorff Rivers in Brittany (middle of the area) have been excluded from the Natura 2000 network; however, they are high probability areas for shad presence. The present modeling approach, therefore, could be used as a tool for the selection of additional protected sites.

Acknowledgements. This study was funded by the French Ministry of Ecology and Sustainable Development ('Programme de connaissance Natura2000 amphihalins en mer'). We are grateful to the French Directorate for Sea Fisheries and Aquaculture (DPMA: Direction des pêches maritimes et de l'aquaculture), the French Research Institute for Exploitation of the Sea (IFREMER: Institut français de recherche pour l'exploitation de la mer), and the National Fisheries Committee (CNPMEM: Comité National des Pêches Maritimes et des Elevages Marins) for providing access to the ObsMer database. We thank B. Dube (IFREMER Lorient) for database assistance. We are also grateful to J. Dimeet and Y. Morizur (IFREMER, Lorient) for relevant discussions. We are grateful to the 3 anonymous referees for their useful comments, which have helped us to improve the manuscript.

\section{LITERATURE CITED}

Akaike H (1974) A new look at the statistical model identification. IEEE Trans Automat Contr 19:716-723

Baglinière JL, Elie P (eds) (2000) Le genre Alosa sp. Cemagref Editions-INRA Editions, Paris

Bethoney ND, Stokesbury KDE, Cadrin SX (2013) Environmental links to alosine at-sea distribution and bycatch in the Northwest Atlantic midwater trawl fishery. ICES J Mar Sci 71:1246-1255

Boisneau C, Moatar F, Bodin M, Boisneau P (2008) Does global warming impact on migration patterns and recruitment of Allis shad (Alosa alosa L.) young of the year in the Loire River, France? Hydrobiologia 602:179-186

Chassé C, Glémarec M (1976) Atlas des fonds meubles du plateau continental du Golfe de Gascogne. Cartes biosédimentaires. Documents I.C.A., Vol 1, Université de Brest

De Groot SJ (2002) A review of the past and present status of anadromous fish species in the Netherlands: Is restocking the Rhine feasible? Hydrobiologia 478:205-218

Dell J, Wilcox C, Hobday AJ (2011) Estimation of yellowfin tuna (Thunnus albacares) habitat in waters adjacent to Australia's East Coast: making the most of commercial catch data. Fish Oceanogr 20:383-396

Dodson JJ, Jones RA, Leggett WC (1972) The behavior of adult American shad (Alosa sapidissima) during migration from salt to freshwater as observed by ultrasonic tracking techniques. J Fish Res Board Can 29:1445-1449

Hanley JA, McNeil BJ (1982) The meaning and use of the area under a receiver operating characteristic (ROC) curve. Radiology 143:29-36

Keil P, Belmaker J, Wilson AM, Unitt P, Jetz W (2013) Downscaling of species distribution models: a hierarchical approach. Methods Ecol Evol 4:82-94

Larsonneur C, Vaslet D, Auffret JP (1979) Les sédiments superficiels de la Manche. Carte Géologique de la Marge Continentale Française. Bureau des Recherches Géologiques et Minieres, Ministere de l'Industrie, Service Géologique National, Orléans

Lassalle G, Trancart T, Lambert P, Rochard E (2008) Latitu- 
dinal variations in age and size at maturity among Allis shad Alosa alosa populations. J Fish Biol 73:1799-1809

Lazure P, Dumas F (2008) An external-internal mode coupling for a 3D hydrodynamical model for applications at regional scale (MARS). Adv Water Resour 31:233-250

Leggett WC, Whitney RR (1972) Water temperature and the migrations of American shad. Fish Bull 70:659-663

Lesueur P, Klingebiel A (1986) Carte des sédiments superficiels du plateau continental du Golfe de GascognePartie septentrionale au 1/500.000. Co-éditée par BRGM \& IFREMER, Brest

Limburg KE, Waldman JR (2009) Dramatic declines in North Atlantic diadromous fishes. Bioscience 59:955-965

Liu C, Berry PM, Dawson TP, Pearson RG (2005) Selecting thresholds of occurrence in the prediction of species distributions. Ecography 28:385-393

Lochet A (2006) Dévalaison des juvéniles et tactiques gagnantes chez la grande alose Alosa alosa et l'alose feinte Alosa fallax: apports de la microchimie et de la microstructure des otolithes. Doctorat, Cemagref, Bordeaux 1, Bordeaux

Loubrieu B, Bourillet JF, Moussat E (2001) Bathy-morphologie régional du Golfe de Gascogne et de la Manche, modèle numérique 2008. Book Rapport Interne IFREMER DCD/GM/CTDI/08-01, IFREMER, Brest

MacKenzie DI (2005) What are the issues with presenceabsence data for wildlife managers? J Wildl Manag 69: 849-860

Neves RJ, Depres L (1979) Oceanic migration of American shad, Alosa sapidissima, along the Atlantic coast. Fish Bull 77:199-212

Editorial responsibility: Stylianos Somarakis,

Heraklion, Greece
Pearcy WG, Fisher JP (2011) Ocean distribution of the American shad (Alosa sapidissima) along the Pacific coast of North America. Fish Bull 109:440-453

Rochard E, Elie P (1994) La macrofaune aquatique de l'estuaire de la Gironde. Contribution au livre blanc de l'Agence de l'Eau Adour Garonne. In: Mauvais JL, Guillaud JF (eds) État des connaissances sur l'estuaire de la Gironde. Agence de l'Eau Adour-Garonne, Bordeaux

> Rougier T, Lambert P, Drouineau H, Girardin M and others (2012) Collapse of allis shad, Alosa alosa, in the Gironde system (southwest France): environmental change, fishing mortality, or Allee effect? ICES J Mar Sci 69:1802-1811

Sabatié MR (1993) Recherche sur l'écologie et la biologie des aloses au Maroc (Alosa alosa Linné, 1758 et Alosa fallax Lacépède, 1803): exploitation et taxonomie des populations atlantiques, bioécologie des aloses de l'oued Sebou. Université de Bretagne Occidentale, Brest

Taverny C, Elie P (2001) Répartition spatio-temporelle de la grande alose Alosa alosa (Linné, 1766) et de l'aose feinte Alosa fallax (Lacépède, 1803) dans le Golfe de Gascogne. Bull Fr Peche Piscicult 362/363:803-821

Vojta CD (2005) Old dog, new tricks: innovations with presence-absence information. J Wildl Manag 69:845-848

Whitehead PJP (ed) (1985) Clupeoid fishes of the world (suborder Clupeioidei). An annotated and illustrated catalogue of the herrings, sardines, pilchards, sprats, shads, anchovies and wolf-herrings, Vol 7. FAO, Rome

Zydlewski J, McCormick SD, Kunkel JG (2003) Late migration and seawater entry is physiologically disadvantageous for American shad juveniles. J Fish Biol 63: 1521-1537

Submitted: January 23, 2014; Accepted: June 6, 2014

Proofs received from author(s): August 25, 2014 